\title{
PENDAMPINGAN PENGELOLAAN KEUANGAN KELUARGA ISLAMI BAGI IBU RUMAH TANGGA PELAKU UMKM DI KECAMATAN JATEN KABUPATEN KARANGANYAR
}

\author{
Tri Nurdyastuti, Cahyani Tunggal Sari, Lukman Ahmad Imron P
}

STIE-AUB Surakarta

tri.nurdyastuti@stie-aub.ac.id

\begin{abstract}
Abstrak
Salah satu elemen utama dalam kegiatan perekonomian keluarga adalah pengelolaan keuangan. Pengelolaan keuangan pribadi dan keluarga dalam Islam sendiri bisa disebut dengan Sakinah Finance. Pengelolaan keuangan keluarga sangat penting bagi kesejahteraan setiap individu dan keluarga dalam kehidupan sehari-hari. Inti dari pengelolaan keuangan Islami adalah pengelolaan dengan menentukan skala prioritas dan anggaran belanja rumah tangga. Ajaran Islam mendesak muslim untuk mengelola keuangan sesuai dengan ajaran Allah untuk memastikan kesuksesan dalam hidup. UMKM adalah singkatan dari Usaha Mikro, Kecil, Menengah. Adapun UUD yang mengatur UMKM adalah Undang - Undang No 20 Tahun 2008 bahwa pemerintah dan pemerintah daerah memfasilitasi pengembang usaha dengan cara memberikan intensif kepada usaha mikro, kecil, dan menengah mengembangkan teknologi dan kelestarian lingkungan hidup. Pelaku UMKM di daerah Jaten belum banyak yang paham arti penting pemisahan keuangan usaha dengan keuangan keluarga sehingga kegiatan PKM ini diharapkan menjadi solusi untuk memperbaiki pengelolaan keuangan tersebut. Tim pengabdian kepada masyarakat tertarik untuk membuat kegiatan pengabdian dengan judul " Pendampingan Pengelolaan Keuangan Keluarga Islami bagi Ibu Rumah Tangga Pelaku UMKM di Kecamatan Jaten Kabupaten Karanganyar “
\end{abstract}

Kata kunci : UMKM, Keuangan keluarga islam, Keuangan Usaha

\begin{abstract}
One of the main elements in family economic activities is financial management.

Management of personal and family finances in Islam itself can be called Sakinah Finance. Management of family finances is very important for the welfare of every individual and family in their daily lives. The essence of Islamic financial management is management by determining the priority scale and household budget. Islamic teachings urge Muslims to manage finances according to God's teachings to ensure success in life. UMKM stands for Micro, Small, Medium Enterprises. The Constitution that regulates MSMEs is Law No. 20 of 2008 that the government and regional governments facilitate business developers by providing intensive micro, small and medium enterprises to develop technology and environmental sustainability. There are not many UMKM entrepreneurs in the Jaten area who understand the importance of separating business finance from family finances so that this PKM activity is expected to be a solution to improve financial management. The community service team was interested in making service activities with the title "Assistance to Islamic Family Financial Management for Housewives of UMKM Actors in Jaten District, Karanganyar Regency"
\end{abstract}

Keywords:UMKM, Islamic family finances, Business finance 


\section{PENDAHULUAN}

Rumah tangga dilihat dari sudut pandang yang sempit ( kehidupan di rumah ) maupun dari

sudut pandang yang luas ( rumah tangga perusahaan maupun rumah tangga negara ) kesemuanya memerlukan tata kelola yang baik, teratur dan terkonsep. Jika salah satu dari ketiga hal tersebut tidak terpenuhi maka stabilitas rumah tangga pasti akan terganggu dan dapat mengakibatkan ketidaksinkronan baik untuk rumah tangga dalam artian kehidupan berumahtangga, rumah tangga perusahaan maupun rumah tangga negara. Strategi nafkah rumah tangga khususnya di pedesaan dibedakan menjadi dua hal, yaitu berdasarkan modal sosial dan modal ekonomi. Perempuan sebagai bagian dari rumah tangga mempunyai peranan yang cukup penting dalam strategi nafkah ini. Keterlibatan perempuan dalam menghasilkan pangan untuk keluarganya bukanlah sesuatu yang baru dan menjadi penting tetapi memang bagian dari hidup perempuan mungkin sejak munculnya peradaban manusia. (Setiowati, t.t.)

Salah satu elemen utama dalam kegiatan perekonomian keluarga adalah pengelolaan keuangan. Pengelolaan keuangan pribadi dan keluarga dalam Islam sendiri bisa disebut dengan Sakinah Finance. Pengelolaan keuangan keluarga sangat penting bagi kesejahteraan setiap individu dan keluarga dalam kehidupan sehari-hari. Inti dari pengelolaan keuangan Islami adalah pengelolaan dengan menentukan skala prioritas dan anggaran belanja rumah tangga. Ajaran Islam mendesak muslim untuk mengelola keuangan sesuai dengan ajaran Allah untuk memastikan kesuksesan dalam hidup. Sebuah keluarga muslim dalam mengelola pembelajaan pada dasarnya harus berprinsip pada pola konsumsi Islami, yaitu berorientasi kepada kebutuhan (need) serta mendahulukan manfaat (utility) dan berusaha mengurangi keinginan yang berlebihan. (Endrianti \& Laila, 2016) Istri dari keluarga dengan suami istri bekerja juga menemukan hasil yang konsisten, bahwasanya manajemen keuangan yang baik mulai dari perencanaan, pengorganisasia, pelaksanaan, hingga pengontrolan keuangan yang baik akan berpengaruh terhadap peningkatan kepuasan istri terhadap keadaan keuangan yang di-milikinya. Manajemen keuangan secara signifikan menurun bila dengan usia istri, besar keluarga, dan lama pernikahan bertambah. Sementara itu, pendidikan istri, pendapatan per kapita keluarga, dan nilai aset keluarga yang semakin bertambah berhubungan signifikan dengan semakin baiknya manajemen keuangan dan kepuasan keuangan istri. Manajemen keuangan yang semakin baik berhubungan signifikan dengan semakin puasnya istri terhadap kondisi keuangannya. Manajemen keuangan dan pendidikan istri memiliki pengaruh yang positif terhadap kepuasan keuangan istri. Dengan demikian, peningkatan kepuasan keuangan istri akan sejalan dengan peningkatan manajemen keuangan yang dilakukan istri dan tingkat pendidikan istri. (Hakim, Sunarti, \& Herawati, 2014).

UMKM adalah singkatan dari Usaha Mikro, Kecil, Menengah. Adapun UUD yang mengatur UMKM adalah Undang - Undang No 20 Tahun 2008 bahwa pemerintah dan pemerintah daerah memfasilitasi pengembang usaha dengan cara memberikan intensif kepada usaha mikro, kecil, dan menengah mengembangkan teknologi dan kelestarian lingkungan hidup. Pelaku UMKM di daerah Jaten belum banyak yang paham arti penting pemisahan keuangan usaha dengan keuangan keluarga sehingga kegiatan PKM ini diharapkan menjadi solusi untuk memperbaiki pengelolaan keuangan tersebut. Tim pengabdian kepada masyarakat tertarik untuk membuat kegiatan pengabdian dengan judul “ Pendampingan Pengelolaan Keuangan Keluarga Islami bagi Ibu Rumah Tangga Pelaku UMKM di Kecamatan Jaten Kabupaten Karanganyar “

\section{RUMUSAN MASALAH}

Perumusan masalah dari kegiatan pengabdian pengelolaan keuangan keluarga bagi ibu rumah tangga pelaku UMKM ini adalah sebagai berikut:

1. Apakah pelatihan strategi pengelolaan keuangan keluarga islami ?

2. Bagaimakah menumbuhkan kesadaran pelaku UMKM khususnya ibu rumah tangga dalam pengelolaan keuangan?

3. Bagaimanakah menumbuhkan kesadaran pelaku UMKM dalam pentingnya pemisahan keuangan keluarga dan usaha.

\section{TINJAUAN PUSTAKA}

\section{Konsep Dasar Sakinah Finance}

Mengatur keuangan keluarga diperlukan kedisiplinan. Jika tidak pintar mengatur, bisa terjadi defisit. Sebaliknya, jika pandai mengatur, pastilah keuangan keluarga akan mengalami surplus. Minimal Setidaknya seimbang, kondisi seimbang ataupun surplus ini akan membuat hati tentram dan tenang. Sesuai artinya, sakinah adalah sebuah kondisi ketenangan dalam sebuah keluarga, tentunya hal itu menjadi dambaan kita semua.

Proses memperoleh pendapatan dan pengeluaran keuangan dengan baik dan benar secara Islami. Jalan menuju Sakinah Finance harus dilakukan dengan niat yang benar, fokus mencari yang halal, bekerja keras, bersilaturahmi, membersihkan harta, bermuhasabah dan bersyukur. Banyak keluarga muda yang hidup dari gaji ke gaji. Lebih mirisnya lagi, hidup dari pinjaman kartu kredit dan lilitan utang. 
Untuk bisa menghindari dan memecahkan masalah tersebut kita bisa diatasi dengan mempelajarinya dalam pengelolaan dan perencanaan.

\section{Nafkah Dalam Keluarga}

Secara prinsip, fitrah kewajiban memberikan nafkah merupakan tanggung jawab suami

sehingga wajib bekerja dengan baik melalui usaha yang halal dan wanita sebagai kaum istri bertanggung jawab mengelola dan merawat aset keluarga. Allah subhanahu wata'ala berfirman: "Kaum laki-laki itu adalah pengayom bagi kaum wanita, oleh karena Allah telah melebihkan sebahagian mereka (laki-laki) atas sebahagian yang lain (wanita), dan karena mereka (laki-laki) telah menafkahkan sebahagian dari harta mereka..." (QS. An-Nisa:34). Dengan demikian, posisi kepala rumah tangga bagi suami paralel dengan konsekuensi memberi nafkah dan komitmen perawatan keluarganya secara lazim.

\section{Manajemen Keuangan Keluarga}

Manajemen keuangan keluarga islami harus dilandasi prinsip keyakinan bahwa penentu dan

pemberi rezki adalah Allah dengan usaha yang diniati untuk memenuhi kebutuhan keluarga agar dapat beribadah dengan khusyu' sehingga memiliki komitmen dan prioritas penghasilan halal yang membawa berkah dan menghindari penghasilan haram yang membawa petaka. Dalam manajemen keuangan keluarga juga tidak dapat dilepaskan dari optimalisasi potensi keluarga termasuk anak- anak untuk menghasilkan rezki Allah. Islam senantiasa memperhatikan masalah pertumbuhan anak dengan anjuran agar anak-anak dilatih mandiri dan berpenghasilan sejak usia remaja di samping berhemat agar pertumbuhan ekonomi keluarga muslim dapat berjalan lancar yang merupakan makna realisasi keberkahan secara kuantitas maka Islam melarang orang tua untuk memanjakan anak-anak sehingga tumbuh menjadi benalu, tidak mandiri dan bergantung kepada orang lain.

\section{Pembelanjaan dan Pola Konsumsi Islami Pengeluaran atau pembelanjaan adalah mengelola harta yang halal untuk mendapatkan}

manfaat material ataupun spiritual sehingga membantu para anggota keluarga dalam memenuhi kebutuhannya. Dalam hal ini terdapat beberapa jenis pembelanjaan yang bermanfaat bagi generasi yang akan datang, dan pembelanjaan dengan jalan baik (amal shaleh) untuk mendapatkan pahala di akhirat, seperti zakat dan sedekah. Syariat Islam mengajarkan beberapa aturan yang mengatur pembelanjaan keluarga muslim, di antaranya secara garis besar adalah Komitmen pembelanjaan dan pemenuhan kebutuhan dana adalah kewajiban suami, Kewajiban menafkahi orang tua yang membutuhkan, Istri Boleh Membantu Keuangan Suami, Istri Bertanggung Jawab Mengatur Keuangan Rumah Tangga, Istri berkewajiban untuk hemat dan ekonomis, Seimbang Antara Pendapatan dan Pengeluaran yang Bermanfaat, Skala Prioritas Pengeluaran (Perlu/Needs Vs Ingin/Wants).

\section{Pemisahan Keuangan Keluarga}

Masih banyak pengusaha yang mencampur antara keuangan pribadi (keluarga) dan

keuangan bisnisnya (perusahaan). Rekening atas namanya juga rekening perusahaannya. Untuk kebaikan, sebaiknya pisahkanlah antara rekening pribadi dan rekening usaha. Setelah porsi ditentukan, langkah berikutnya adalah melakukan pencatatan keuangan usaha. Memang jika usaha skalanya masih kecil, kita cenderung menyamakan uang yang diterima usaha dan uang pribadi. Bahkan kita biasanya menyimpan uang itu dalam satu nomor rekening. Tapi jika keuangan usaha dan bisnis dijadikan satu, kita akan kesulitan melakukan monitoring pendapatan atau pun pengeluaran. Dengan memisahkan pencatatan keuangan usaha dengan keuangan pribadi akan lebih mudah membedakan antara arus dana dari usaha dan penggunaan uang untuk kepentingan pribadi. Sepenting melakukan pemisahan rekening pribadi dengan rekening usaha adalah pemisahan pencatatan, karena dapat memberika informasi lebih jelas keadaan finansial usaha.

Poin penting dalam pengaturan keuangan adalah disiplin diri. Memang kunci utama mengatur keuangan usaha adalah disiplin mematuhi porsi yang kita atur untuk keuangan usaha dan pribadi. Berbagai macam godaan sering muncul. Barang-barang tadinya belum terlalu penting jadi seperti "minta dibeli". Ada kalanya saat uang masuk dalam jumlah besar, kita merasa butuh ini dan itu. Kita harus dapat membedakan kebutuhan dan keinginan. Sebelum membeli sesuatu dengan alasan usaha, tanyakan dulu apakah merupakan kebutuhan mendesak atau keinginan yang bisa ditunda. Jawabannya akan membantu kita tidak menentukan ke mana uang akan digunakan.

\section{TARGET}

Target dari Kegiatan Pengabdian

Masyarakat "Pendampingan Pengelolaan

Keuangan

Keluarga Islami bagi Ibu Rumah Tangga Pelaku UMKM di Kecamatan Jaten Kabupaten Karanganyar" yaitu Ibu Rumah Tangga Pelaku UMKM di Kecamatan Jaten mampu mengelola keuangan keluarga secara islami dan mampu memisahkan antara keuangan keluarga dan keuangan usaha. 


\section{LUARAN}

Luaran dari Kegiatan Pengabdian

Masyarakat "Pendampingan Pengelolaan

Keuangan

Keluarga Islami bagi Ibu Rumah Tangga Pelaku UMKM di Kecamatan Jaten Kabupaten

Karanganyar" yaitu karya ilmiah / jurnal yang dipublikasikan.

\section{SOLUSI YANG DITAWARKAN}

Tim Pengabdian Kepada Masyarakat memberikan solusi dalam bentuk sosialisasi strategi

pengelolaan keuangan terkait dengan permasalahan yang terjadi di lapangan. Adapun solusi yang diberikan oleh Tim Pengabdian Masyarakat antara lain:

1. Penjelasan tentang pengelolaan keuangan keluarga dan manfaatnya

2. Pelatihan penyusunan keuangan keluarga yang tepat

\section{BENTUK KEGIATAN}

Kegiatan Pengabdian Kepada Masyarakat ini berbentuk ceramah, simulasi dan diskusi

kepada kelompok UMKM dengan tujuan memberikan edukasi kepada pelaku UMKM di Kabupaten Karanganyar akan pentingnya pengelolaan keuangan keluarga agar tidak mempengaruhi keuangan usaha.

HASIL

Hasil kegiatan pengabdian kepada masyarakat sebagai berikut:

1. Kegiatan Pengabdian Masyarakat ini diikuti oleh ibu rumah tangga pelaku UMKM di

Kecamatan Jaten. Jadwal pelaksanaan pelatihan sebagai berikut: Waktu (hari dan Tanggal) : Sabtu / 23 Februari 2019

Tempat : Jaten

Peserta pelatihan yang hadir dalam kegiatan pengabdian kepada masyarakat sejumlah 23 orang (data terlampir)

2. Pada kesempatan tersebut, ketua dan anggota tim kegiatan pengabdian pada masyarakat ini membagikan pretest materi dan dikerjakan peserta.

3. Narasumber menyampaikan materi kemudian melakukan postest dan dikerjakan kembali oleh peserta.

\section{PEMBAHASAN}

Pada pembahasan ini disajikan analisis hasil pengolahan data dari hasil pretest dan posttest yang dilakukan tim pada saat pengabdian. Analisis dilakukan dengan menggunakan uji beda untuk mengetahui apakah terdapat perbedaan pemahaman tentang materi yang diberikan sebelum pelatihan dan sesudah pelatihan. Hasil analisis data sebagai berikut:

Tabel IV.1

Hasil Analisis Data

Paired Samples Statistics

\begin{tabular}{|c|c|c|c|c|c|}
\hline & & Mean & $\mathrm{N}$ & Std. Deviation & $\begin{array}{l}\text { Std. Error } \\
\text { Mean }\end{array}$ \\
\hline \multirow{2}{*}{$\begin{array}{l}\text { Pair } \\
1\end{array}$} & Pre test & 54,3478 & 23 & 11,60959 & 2,42077 \\
\hline & Post test & 85,2174 & 23 & 6,11969 & 1,27604 \\
\hline
\end{tabular}

Paired Samples

Test

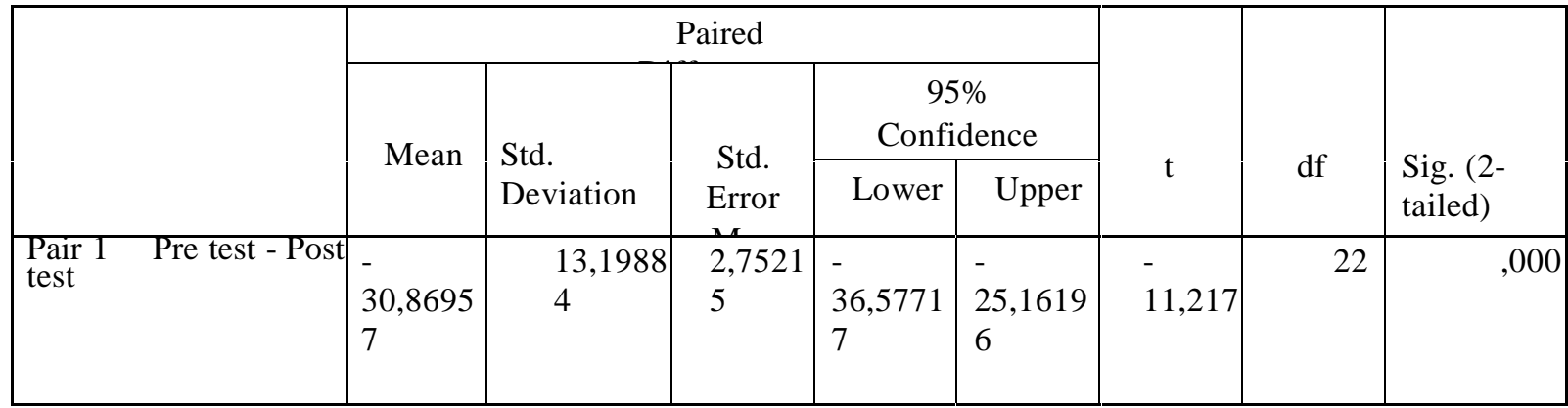

Dari hasil diatas menunjukkan bahwa ratarata pemahaman terhadap materi sebelum dan sesudah dilakukan pelatihan pada peserta. Sebelum pelatihan rata-rata pemahaman terhadap materi dari 23 orang peserta adalah sebesar 54,3, sementara setelah diberikan pelatihan rata-rata pemahaman peserta 
sebesar 85,2. Nilai t hitung sebesar $-11,217$ dengan sig $0.000<0.05$, artinya rata-rata pemahaman sebelum dan sesudah pelatihan Training of Trainer terhadap peserta terdapat perbedaan. Dengan demikian dapat dinyatakan bahwa penyampaian materi sangat mempengaruhi terhadap pemahaman peserta pelatihan.

\section{KESIMPULAN}

Berdasarkan hasil dan pembahasan kegiatan pengabdian kepada masyarakat yang telah

diuraikan sebelumnya, dapat disimpulkan bahwa :

1. Pemahaman peserta tentang pengelolaan keuangan keluarga secara islami semakin tinggi setelah mengikuti pelatihan.

2. Kemampuan peserta pelatihan meningkat dalam mengelola keuangan keluarga secara islami dan pemisahan keuangan keluarga dengan keuangan usaha.

\section{SARAN}

Penyelenggaraan program pengabdian kepada masyarakat dengan bentuk Pendampingan Pengelolaan Keuangan Keluarga Islami bagi Ibu Rumah Tangga Pelaku UMKM di Kecamatan Jaten penyelenggaraan diharapkan kegiatan seperti dapat dilakukan secara berkesinambungan.

\section{DAFTAR PUSTAKA}

Endrianti, R. D., \& Laila, N. (2016). Pengelolaan

Keuangan Keluarga Secara Islam Pada Keluarga Muslim Etnis Padang Dan Makassar Di Surabaya1), 3(7), 12.

Hakim, F. A., Sunarti, E., \& Herawati, T. (2014). Manajemen Keuangan dan Kepuasan Keuangan Istri pada Keluarga dengan Suami Istri Bekerja. Jurnal Ilmu Keluarga dan Konsumen, 7(3), 174-182. https://doi.org/10.24156/jikk.2014.7.3.17 4

Setiowati, N. E. (t.t.). Perempuan, Strategi Nafkah Dan Akuntansi Rumah Tangga, 7.

Muhammad (2016). Mengelola Keuangan Rumah Tangga Yang Islami . Diakses pada 28 Februari 2018 pukul 19.00. https://pengusahamuslim.com/3631mengelola-keuangan-rumah- tanggayang-1850.html

Iyaningsih (2017). Sakinah Finance.Diakses pada 28 Februari 2018 pukul 19.00 .

https://www.kompasiana.com/iyasningsi h/5a5a0faccbe5231bf66df052/merencan akan- sakinah-finance-di-tengahbudaya-hedonisme-berbasis-perbankansyariah?page $=$ all

Wirawan,Guritno. (2017). Pisahkan Uang Pribadi Dan Uang Perusahaan. Diakses pada 28 Februari 2018 pukul 20.00 . https://pengusahamuslim.com/3753pisahkan-uang-pribadi-dan- uang1913.html 